\subsection{4/hsuf.2018.10.03}

Андрій Усач

\section{«ЩОБ ВОНИ БІЛЬШЕ НЕ ХОДИЛИ ПО НАШІЙ СВЯТІЙ ЗЕМЛІ»: КДБ УРСР І ПОЛІТИКА ПАМ'ЯТІ ПРО МІСЦЕВУ КОЛАБОРАЦІЮ, 1960-1980-ті pp.}

Для радянської України 1960-1980-х рр. проведення публічних судових процесів стало невід'ємною частиною так званої «другої хвилі» переслідування колишніх колаборантів у СРСР. За ініціативою КДБ ці процеси являли собою важлливу складову ширшої кампанії з інструменталізації подій Другої світової війни, нацистської окупації та Голокосту. Активна участь КДБ у створенні та розповсюдженні пропагандистської продукції як для внутрішнього, так $і$ закордонного споживача є безумовною. Майже завжди за цією діяльністю було намагання використати травматичну тему для вирішення актуальних політичних питань.

Основним зовнішнім фактором, який впливав на діяльність КДБ у цей час, без сумніву була «холодна війна», чергове загострення якої припало на початок 1960-х рр. У цьому ракурсі особливу увагу КДБ УРСР звертав на українську діаспору, вбачаючи загрозу в тому, що західні спецслужби використовують ї̈ з антирадянською метою, у тому числі й через приватні контакти з родичами в УРСР. А тому з 1960-х рр. бере початок активніше акумулювання та оприлюднення інформації про тих членів діаспорних спільнот, які під час Другої світової війни співпрацювали з нацистами. Таким чином радянські органи безпеки намагались затаврувати всі ці спільноти як суцільних колаборантів, а країни Заходу як такі, що навмисне надають їм прихисток.

Не менш важливими в контекстуалізації діяльності КДБ у зазначений період були внутрішні фактори, зокрема боротьба з національними рухами (українським, кримськотатарським, єврейським), дисидентськими групами, релігійними течіями. Це було тим більш важливо з огляду на паралельний процес конструювання «єдиної радянської ідентичності» і міфу про Велику Вітчизняну війну як ї̈ складову і центральну частину.

Стаття присвячена дослідженню ролі КДБ УРСР в інструменталізації явища місцевої колаборації в 1960-1980-х рр.

${ }^{1}$ Висловлюю щиру вдячність Дмитру Джулаю, Ірині Єзерській, Роману Михальчуку, Тетяні Пастушенко та Ірині Склокіній за допомогу в підготовці тексту статті.
Автор намагається простежсти реакцію на цю діяльність серед населення України в коротко- та довготерміновій перспективах. Основу джерельної бази склали доступні віднедавна документи з архівів Служби безпеки України.

Ключові слова: Колаборація, КДБ УРСР, судові процеси, інструменталізація, участь у Голокості.

У червні 1972 р. в районному центрі Володимирець на Рівненщині відбувся публічний судовий процес над групою з п'яти осіб, яких обвинувачували в тому, що під час нацистської окупації вони служили в Рафалівській районній поліції та брали участь у здійсненні численних актів насильства, зокрема масового вбивства 2500 місцевих євреїв в урочищі «Бахова гора» в серпні 1942 р. Після цього вони займались пошуками тих, кому вдалося врятуватись, виявлених євреїв вбивали, а їх майно розграбовували. У результаті виїзною сесією Рівненського обласного суду двоє підсудних, Володимир та Арсентій Панасюки, були засуджені до розстрілу, ще двоє, Олексій Скибчик та Іван Паламарчук, - до 15 і один, Георгій Паламарчук, - до 10 років ув'язнення². Цей процес активно висвітлювався в пресі, автором найвідомішого тексту під назвою власне «Бахова гора» став Олександр Федрицький, тодішній кореспондент обласної газети «Червоний прапор» ${ }^{3}$.

Для радянської України зразка 1960-1980-х рр. це не було унікальною подією. Проведення публічних судових процесів стало невід'ємною частиною так званої «другої хвилі» переслідування колишніх колаборантів у СРСР. Встановити їх точну кількість за цей період важко, але, до прикладу, впродовж того ж 1972 р. відбулося ще шість подібних процесів у Волинській, Дніпропетровській, Кіровоградський, Кримській, Полтавській та Чернігівській областях, у результаті яких дев'ять осіб було засуджено до розстрілу, чотири до 15 і один - до 13 років ув'язнення". Останній з таких процесів мав місце у квітні 1989 р. і стосувався колишнього поліцейського Ганса Кампфа з Житомирщини, засудженого до розстрілу'. Вже в березні

\footnotetext{
${ }^{2}$ Архів управління Служби безпеки України у Рівненській області (далі- АУСБУРО), ф. 4, спр. 19090, т. 1-15.

${ }^{3}$ Олександр Федрицький, «Бахова гора», в Зуби дракона. Публіцистичні нариси і памфлети (Київ: Дніпро, 1988), 78-91.

${ }^{4}$ Підраховано за: Галузевий державний архів Служби безпеки України (далі - ГДА СБУ), ф. 16 спр. 1005, арк. 64-67; ГДА СБУ, Ф. 16, спр. 1006, арк. 50-51; ГДА СБУ, Ф. 16, спр. 1012, арк. 102 206, 294-295; ГДА СБУ, ф. 16, спр. 1019, арк. 24-25.

${ }^{5}$ Архів управління Служби безпеки України у Житомирській області (далі- АУСБУжО), ф. 5 , спр. 32437, т. $1-8$.
} 
1990 р. у Херсоні був заарештований Микола Травкін, теж колишній поліцейський. В його справі так само планувався публічний судовий процес ${ }^{6}$. Однак жодної інформації про те, чи такий відбувся, виявити не вдалося, тому найвірогідніше буде припустити, що від ідеї його проведення відмовились в умовах розпаду СРСР.

Досі «друга хвиля» переслідування колишніх колаборантів привертала мало уваги з боку дослідників, на відміну від подій воєнної доби та періоду пізнього сталінізму, що виглядає цілком зрозуміло 3 огляду на масштаби - у 1943-1953 рр. за співпрацю з нацистськими окупантами по УРСР було засуджено 93590 осіб'. При цьому лише невелика частина пройшла через публічні судові процеси, у поодиноких випадках відбулися привселюдні страти. Це була складова легітимації радянської влади на деокупованих територіях. У Західній Україні застосування такої практики було тісно пов’язано із затяжною боротьбою проти українського націоналістичного руху ${ }^{8}$. Попри порівняно невелику кількість досліджень, в яких би зверталась увага на подібні події в 1960-1980-х рр., вже можна відзначити деякі важливіші праці. Зокрема, текст Лева Сімкіна про перипетії навколо процесу у справі колишніх охоронців нацистських концтаборів, що відбувся в Києві в березні 1962 р., може слугувати прикладом скрупульозного дослідження окремо взятого випадку' ${ }^{\circ}$ Переконливий аналіз контекстів у подібних процесах упродовж 1960-х рр. подав Александр Прусін $^{10}$. Ірина Склокіна розглянула мінливість радянської політики пам’яті щодо явища місцевої колаборації, зосередивши увагу на іiї регіональних особливостях".

\footnotetext{
$\overline{6}$ «Каратель изобличен», Информационный бюллетень КГБ СССР 4 (1990): 6
}

${ }^{7}$ Тетяна Пастушенко, ««Правосуддя» по-радянськи: кваліфікація співпраці з нацистами в СРСР, 1941-1956 рр.», Сторінки воєнної історії України 16 (2013): 125.

${ }^{8}$ Детальніше див.: Тамара Вронська, «Феміда воєнної доби і цивільне населення», Сторінки воєнної історії України 3 (1999): 100-119; Franziska Exeler, «The Ambivalent State: Determining Guilt in the Post-World War II Soviet Union», Slavic Review 75, no. 3 (2016): 606-629; Tanja Penter, «Local in the Post-World War Il Soviet Union", Slavic Review 75, no. 3 (2016): 606-629; Tanja Penter, "Local
Collaborators on Trial: Soviet War Crimes Trials under Stalin (1943-1953)", Cahiers du Monde russe 49, no. 2-3 (2008): 341-364; Amir Weiner, Making Sense of War: The Second World War and the Fate of the Bolshevik Revolution (Princeton: Princeton University Press, 2001).

${ }^{9}$ Lev Simkin, «Death Sentence Despite the Law: A Secret 1962 Crimes-against-Humanity Trial in Kiev», Holocaust and Genocide Studies 27, no. 2 (2013): 299-312.

${ }^{10}$ Alexander V. Prusin, «The "Second Wave» of Soviet Justice: The 1960s War Crimes Trials», in Rethinking Holocaust Justice: Essays across Disciplines, ed. Norman J.W. Goda (New York: Berghahn Books, 2018), 129-157.

11 Ірина Склокіна, «Радянська політика пам'яті про колаборацію періоду нацистської окупації як інструмент національної політики: регіональний аспект», Національна та історична пам'ять 5 (2012): 118-141.
Метою запропонованого тексту є дослідження ролі КДБ УРСР в інструменталізації явища місцевої колаборації в 1960-1980-х рр. та здійснення спроби простежити реагування на цю діяльність серед населення України в коротко- та довготерміновій перспективах. Ocнову джерельної бази склали доступні віднедавна документи з архівів Служби безпеки України.

У післясталінський період КДБ був реформований, зокрема його діяльність почала більше контролюватись з боку партійних структур $^{12}$. Після наказу Президії Верховної Ради СРСР «Про амністію радянських громадян, які співпрацювали з окупантами в період Великої Вітчизняної війни 1941-1945 рр.», від 17 вересня 1955 р. почалось масове звільнення з ГУЛАГу колишніх колаборантів, за винятком засуджених за «вбивства і катування радянських громадян», та припинення справ щодо тих із них, хто на час оприлюднення наказу перебував під слідством ${ }^{13} .3$ одного боку, це означало, що співробітники КДБ мали приділяти цьому напрямку своєї діяльності набагато менше уваги, а з іншого - вже в липні 1962 р. їм у провину почали ставити відсутність належного спостереження за звільненими 3 ГУЛАГу «крупними карателями та пособниками». Остаточні вказівки щодо активізації діяльності в цьому напрямку було прийнято за три роки, а саме 4 березня 1965 р., коли з'явився наказ Президії Верховної Ради СРСР «Про покарання осіб, винних у злочинах проти миру і людяності і воєнних злочинах, незалежно від часу скоєння злочинів». Згідно з ним нацистські злочинці повинні були притягатись до відповідальності без огляду на те, скільки часу пройшло після вчинених ними злочинів ${ }^{15}$. Про місцевих колаборантів у тексті цього наказу не йшлося. Проте в постанові щодо його застосування від 3 вересня 1965 р. додатково роз'яснювалось, що дія наказу поширюється

${ }_{12}$ Детальніше див.: Олег Бажан, «Реформування органів держбезпеки УРСР у 1950 - першій половині 1960-х рр.», в Радянські органи державної безпеки в Україні (1918-1991 рр.): історія, структура, функції, упор. Олег Бажан і Роман Подкур (Київ: Інститут історії України НАНУ, 2013), 312-333.

${ }^{13}$ Андрей Артизов и др. сост., Реабилитация: как это было. Документы Президиума ЦК КПСС и другие материалы (Москва: МФД, 2000), 1: 259-260.

${ }^{14}$ Александр Кокурин и Никита Петров сост., Лубянка: Органы ВЧК-ОГПУ-НКВД-МГБ-МВД-КГБ, 1917-1991: справочник (Москва: МФД, 2003), 705.

${ }^{15}$ Михаил Юмашев, А. Калитеевская и Р. Владимирцев сост., Сборник законов СССР и указов Президиума Верховного Совета СССР: 1938-1975 (Москва: Известия Советов депутатов трудящихся СССР, 1975), 3: 343-344. 
і на громадян СРСР, які «проводили активну каральну діяльність, брали особисту участь у вбивствах і катуваннях радянських людей»'.

Основним зовнішнім фактором, який впливав на діяльність КДБ у цей час, без сумніву була «холодна війна», чергове загострення якої припало на початок 1960-х рр. У цьому ракурсі особливу увагу КДБ УРСР звертав на українську діаспору, вбачаючи загрозу в тому, що західні спецслужби використовують пї з антирадянською метою, у тому числі й через приватні контакти з родичами в УРСР. А тому з початку 1960-х рр. бере початок активніше акумулювання та оприлюднення інформації про тих членів діаспорних спільнот, які під час Другої світової війни співпрацювали 3 нацистами, цим самим намагаючись затаврувати всі ці спільноти як суцільних колаборантів, а країни Заходу як такі, що навмисне надають їм прихисток. СРСР же в цій схемі відводилась роль єдиної держави, що не зрадила ідеалів антифашизму і продовжує систематичне переслідування нацистських злочинців і їх поплічників. Основні тези цієї схеми стисло виклали Борис Бабій та Гліб Чангулі з Інституту держави і права Академії наук УРСР у лютому 1987 р.: «Як відомо, ще під час війни проти фашизму держави - члени антигітлерівської коаліції зобов'язалися розшукати воєнних злочинців, де б вони не переховувались і віддати їх до рук правосуддя. Радянський Союз неухильно виконує свої міжнародні зобов'язання. Переважна більшість нацистських воєнних злочинців, виявлених на території СРСР, віддані до суду і зазнали належного покарання... Цього не можна сказати про західні країни, де внаслідок пособництва властей величезній кількості нацистських воєнних злочинців вдалося уникнути покарання»". Попри те, що на межі 1950-1960-х рр. на Заході також починається чергова хвиля переслідування нацистських злочинців, їі масштаби були незначними, що своєю чергою робило подібні критичні заяви з радянського боку не позбавленими сенсу. При цьому мало місце і співробітництво між СРСР та країнами соціалістичного табору, а також США, ФРН. Як заявляв у 1986 р. перший заступник генерального прокурора СРСР Микола Баженов, 417 закордонних юристів відвідали СРСР для допитів понад 600 свідків, ще 195 свідкам було забезпечено виїзд закордон для участі в судових процесах ${ }^{18}$.

${ }^{16}$ Юмашев, Калитеевская и Владимирцев, сост., Сборник законов СССР и указов Президиума Верховного Совета СССР, 344

${ }^{17}$ Борис Бабій і Гліб Чангулі, «Суворі уроки історії», Вісті з України, № 6, 1987

${ }^{18}$ Николай Баженов, «Нерушимость принципов Нюрнберга и сотрудничество государств в преследовании нацистских военных преступников", в Нюрнбергский процесс и современность (Москва: Институт государства и права Академии наук СССР, 1986), 98.
Очевидно, це була свого роду ширма і за бажанням покарати тих, хто був винуватцем масового насильства під час Другої світової війни, артикульованим в офіційному радянському дискурсі, приховувались дещо інші інтереси. Зокрема, у вказівках КДБ від 30 серпня 1962 р. вказувалось щодо колишніх колаборантів у середовищі української діаспори у країнах Заходу": «Багато із цих осіб викликають зацікавлення в плані проведення заходів з їх компрометації, можливого оперативного використання закордоном органами держбезпеки, а також порушення питання через МЗС СРСР перед урядами відповідних капіталістичних держав про видачу їх радянській владі для притягнення до кримінальної відповідальності» ${ }^{20} 3$ другої половини 1970-х рр. діяльність КДБ у цьому напрямку систематизувалась в рамках довготермінової акції «Відплата», яка полягала в тому, що до державних структур спершу США, а потім також Канади, Великобританії, Австралії почали надсилати інформацію про злочинну діяльність тих або інших осіб та провокувати їх переслідування. Паралельно з цим неофіційними шляхами ця інформація передавалась до преси, громадських організацій тощо ${ }^{21}$ Упродовж 19761981 рр. лише до США були передані дані на близько 300 таких осіб ${ }^{22}$. У внутрішній документації КДБнеприховувалось, щовся ця діяльність була політично вмотивованою. До прикладу, інформація щодо британського громадянина Кирила Зварича, колишнього поліцейського з Волині, була відома КДБ, але «до тих пір, поки відносини з Англією розвивались благопристойно, реалізовувати наявні матеріали було недоцільно». Її почали навмисно оприлюднювати лише після шпигунського скандалу i, як його результату, висилки з Великобританії 105 радянських дипломатичних співробітників у вересні 1971 p. $^{23}$ Після цього документування силами КДБ фактів щодо діяльності Зварича під час нацистської окупації і їх оприлюднення стали систематичними ${ }^{24}$. Так само в КДБ стежили за консолідаційними

\footnotetext{
${ }_{19}$ У документі йшлося про США, Великобританію, Канаду, ФРН, Францію, Австралію, Аргентину, Голландію та Бельгію.

${ }^{20}$ ГДА СБУ, ф. 16, спр. 932, арк. 150-151.

${ }^{21}$ ГДА СБУ, ф. 16, спр. 1061, арк. 124-125; ГДА СБУ, ф. 16, спр. 110, арк. 169-170; ГДА СБУ, ф. 16, спр. 1119, арк. 28-29.

${ }_{22}$ ГДА СБУ, ф. 16, спр. 1085, арк. 141-142.

${ }^{23}$ Владимир Шищенко, «К вопросу о понятии и методах разложения эмигрантских антисоветских организаций», Труды высшей школы КГБ СССР 43 (1988): 152.

${ }^{24}$ Архів управління Служби безпеки України у Волинській області (далі- АУСБУВо0), ф. 5, спр. 23102, т. 1-3. Приклади публікацій див.: «Нота МИД СССР посольству Великобрита-
} 
процесами серед української діаспори, особливо болісно реагуючи на спроби порозуміння з єврейськими та польськими середовищами ${ }^{25}$. Практичні результати такої діяльності були більш ніж скромними. До прикладу, впродовж 1981-1987 рр. всього 10 колишніх колаборантів з України були позбавлені американського громадянства, а до СРСР передали лише одного з них - колишнього охоронця нацистських таборів смерті Федора Федоренка. Він був засуджений до розстрілу на

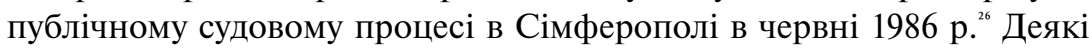
зі скомпрометованих КДБ осіб помирали в результаті інфарктів, нервових зривів або вчиняли самогубства ${ }^{27}$. Значно більших успіхів вдалося досягти в питанні екстрадиції до СРСР колишніх колаборантів, які після війни опинились в країнах соцтабору. До прикладу, у травні 1966 р. на території Румунії був заарештований Георге Андрухов, який виявився Григорієм Андрусівим - колишнім комендантом Барської районної поліції на Вінниччині. У жовтні того ж року в місті Бар відбувся публічний судовий процес, на якому його засуджено до розстрілу ${ }^{28}$. Ще до цього в пресі було опубліковано кілька статей, в яких, крім Андрусіва, фігурували особи його заступника Олексія Кеби з дружиною. На той час обидва жили у Бразилії, у статтях наводились їхні актуальні адреси та демонструвалася перевага радянського правосуддя над його західними аналогами ${ }^{29}$. При цьому деяких виявлених у країнах соцтабору колишніх колаборантів навіть не вимагали передати до СРСР. Натомість їх судили в тих країнах, громадянами яких вони були на той час, а КДБ зі свого боку забезпечував організаційну підтримку, зокрема прибуття свідків ${ }^{\text {30. }}$.

Набагато помітніші результати КДБ вбачав у пропагандистському ефекті від своєї діяльності. У лютому 1988 р. в одному зі звітів із задоволенням цитувались слова співробітника радіостанції «Свобода» Богдана Нагайла про те, що «на кожного націоналіста в США

нии в Москве», Известия, № 123, 1972; Полікарп Шафета, «Відкритий лист прем'єр-міністрові Великобританії Маргарет Тетчер», Вісті з України, № 38, 1986.

${ }^{25}$ ГДА СБУ, ф. 16, спр. 1109, арк. 122-123; ГДА СБУ, ф. 16, спр. 1112, арк. 68.

${ }^{26}$ ГДА СБУ, Ф. 16, спр. 1113, арк. 207-208.

${ }^{27}$ ГДА СБУ, ф. 16, спр. 1089, арк. 212; ГДА СБУ, ф. 16, спр. 1101, арк. 295; ГДА СБУ, ф. 16, спр. 1114, арк. 109-110.

${ }^{28}$ Архів управління Служби безпеки України у Вінницькій області (АУСБУВО), ф. 5, спр. 28506, т. 1-6.

${ }^{29}$ Н. Лапинский и В. Шмыгановский, «У последней черты», Известия, № 238, 1966.

${ }^{30}$ До прикладу, див. про суд над Олексюком, колишнім поліцейським з Рівненщини, що відбувся в січні 1982 р. у Вроцлаві: ГДА СБУ, ф. 16, спр. 1093, арк. 37-38. обиватель дивиться тепер як на нациста, погромщика, воєнного злочинця»". Це стосувалося, очевидно, ставлення не лише до членів націоналістичних організацій, а й загалом до представників українських діаспорних спільнот на Заході. Приміром, до позитивних наслідків зараховувалось й те, що на парламентських виборах у Канаді в 1987 р. із 40 кандидатів-українців було обрано лише $7^{32}$. Важливим вважалося й те, що діаспора все більше зусиль та фінансових ресурсів почала вкладати у протидію заходам, до здійснення яких КДБ був причетний тим чи іншим чином ${ }^{33}$. «Зокрема, на правовий захист у період роботи комісії Дешена «Комітет українців Канади» витратив 1,2 млн доларів; захист карателя Дем'янюка обійшовся в 600 тис. доларів і оголошено новий збір пожертв на ці цілі» - підраховувалось в одному зі звітів ${ }^{34}$.

Не менш важливими в контекстуалізації діяльності КДБ у зазначений період були внутрішні фактори. Передусім, йдеться про боротьбу з національними рухами - українським, кримськотатарським, єврейським, - дисидентськими групами, релігійними течіями ${ }^{35}$. Це було тим більш важливо з огляду на паралельний процес конструювання «единої радянської ідентичності» і міфу про Велику Вітчизняну війну як її складової і центральної частини ${ }^{36}$. Вже в липні 1967 р. в структурі КДБ було створено окремий, 5-й, відділ з боротьби з ідеологічними диверсіями, який діяв у цьому напрямку. У постанові Політбюро ЦК КПРС від 17 липня 1967 р. про його створення особлива увага зверталась на наявність у СРСР значного числа репатріантів та осіб, звільнених з ГУЛАГу, серед яких було чимало місцевих колаборантів, і висловлювалось занепокоєння щодо ведення ними антирадянської діяльності ${ }^{37}$. Голова КДБ Юрій Андропов у грудні 1975 р. серед потенційних противників режиму також називав «колишніх карателів та інших пособників німецько-фашистських окупантів» ${ }^{38}$. Додатковим поштовхом для актуалізації діяльності КДБ

\footnotetext{
${ }^{31}$ ГДА СБУ, ф. 16, спр. 1119, арк. 31.

32 ГДА СБУ, ф. 16, спр. 1119, арк. 31.

${ }^{33}$ ГДА СБУ, ф. 16, спр. 1110, арк. 170.

${ }^{34}$ ГДА СБУ, ф. 16, спр. 1119, арк. 31.
}

${ }_{35}$ До прикладу, див. про використання теми місцевої колаборації при здійсненні КДБ заходів проти прибічників нелегальної Істинно-православної церкви: ГДА СБУ, ф. 16, спр. 1069, арк. 213. ${ }^{36}$ Николай Копосов, Память строгого режима: история и политика в России (Москва: Новое литературное обозрение, 2011), 102-105.

${ }^{37}$ Кокурин и Петров, сост., Лубянка, 711-714.

${ }^{38}$ Алексей Макаров, Николай Костенко и Геннадий Кузовкин сост., Власть и диссиденты: из документов КГБ и ЦК КПСС (Москва: Московская Хельсинская Группа, 2006), 92. 
у цьому напрямку стала постанова ЦК КПРС «Про заходи щодо подальшого підвищення політичної пильності радянських людей» від 23 травня 1977 p. $^{39}$

Також не слід ігнорувати ініціативи знизу. У зв'язку із колосальними масштабами нацистського насильства в Україні багато місцевих мешканців самі стали його жертвами, втратили рідних тощо. Винуватцями цього часто були й місцеві колаборанти, а відтак було чимало зацікавлених у притягненні їх до відповідальності. Свою роль могли відіграти і майнові конфлікти після повернення амністованих з ГУЛАГу. До КДБ постійно надходили сигнали про злочинну діяльність під час нацистської окупації тих чи інших осіб. До прикладу, у 1979 р. було отримано 871 таку заяву, у 1988 р. - 248, у $1989-162^{40}$. Хоча, як помітно, їх кількість і зменшувалась, але продовжували надходити вони до самого розпаду СРСР ${ }^{4}$. Приміром, розслідування у вже згаданій справі Кампфа розпочалось саме після такої заяви ${ }^{42}$. Про фактор ініціативи знизу можуть свідчити і запитання, які ставили співробітникам КДБ під час лекцій щодо «підвищення політичної пильності радянських людей». Їх сумлінно нотували: «Чи всі особи виявлені і понесли заслужене покарання за каральну діяльність в період Великої Вітчизняної війни?» (Житомир, 1981 р.), «Чому останнім часом не притягають до кримінальної відповідальності тих, хто в роки війни являвся активним пособником гітлерівців?» (Полтава, 1982 р.), «У випадку, якщо з-за кордону приїжджають в СРСР колишні бандити ОУН або карателі, чи притягають їх до кримінальної відповідальності?» (Тернопіль, 1983 р.) тощо ${ }^{43}$.

Отже, ціла низка факторів впливала на те, що з початку 1960-х рр. КДБ почав більше уваги звертати на проблему місцевої колаборації, і відповідно змушувала до пошуку відповідного інструментарію для іiі використання з метою вирішення актуальних політичних завдань. Серед іншого, КДБ курував видання відповідної пропагандистської літератури, створення радіо- та телепередач, документальних фільмів. Для розуміння масштабів цього напрямку діяльності можна навести дані за 1984 р., упродовж якого співробітники держбезпеки взяли участь у створенні 8 документальних фільмів, 16 книг і брошур,

\footnotetext{
${ }^{39}$ Макаров, Костенко и Кузовкин, сост., Власть и диссиденты, 190.

${ }^{40}$ ГДА СБУ, ф. 16, спр. 1135, арк. 164; ГДА СБУ, ф. 16, спр. 1137, арк. 186.

${ }^{41}$ ГДА СБУ, ф. 16, спр. 1138, арк. 26.

${ }^{42}$ АУСБУЖО, ф. 5, спр. 32437, т. 2, арк. 2-3.

${ }^{43}$ ГДА СБУ, ф. 16, спр. 1088, арк. 251; ГДА СБУ, ф. 16, спр. 1096, арк. 228; ГДА СБУ, ф. 16, спр. 1104, арк. 94.
}

882 памфлетів і статей, 395 радіо- та телепередач ${ }^{44}$. У червні 1980 р. КДБ звернувся до ЦК КПУ з пропозицією створити документальну стрічку за результатами судового процесу над колишніми поліцейськими Миколою Дуфанцем, Артемом Бубелою та Пилипом Рибачуком, який відбувся 5-28 серпня 1980 р. в райцентрі Стара Вижівка на Волині: «У зв’язку зі зростаючою ворожою активністю закордонних оунівських центрів вихід зазначеного фільму на екрани в цьому році відіграв би важливу роль у посиленні наших загальнопрофілактичних i контрпропагандистських заходів щодо подальшого викриття антинародної сутності українського буржуазного націоналізму, кривавих злодіянь оунівських банд, а також компрометації спроб, які вживають ватажки ОУН, з консолідації своїх злочинних дій з екстремістськими устремліннями сіоністських лідерів». Створення такої стрічки пропонувалось доручити «Укркінохроніці», у чому голова КДБ УРСР Віталій Федорчук зі свого боку обіцяв «необхідну допомогу» ${ }^{45}$. Наступного року відповідна стрічка під назвою «Без строку давності» була знята режисером Евгеном Татарцем ${ }^{46}$. Очевидно, що для цього КДБ не міг обходитись лише власними кадрами, а повинен був налагоджувати співпрацю з авторами на кшталт згаданих Федрицького чи Татарця, проте характер такого роду співпраці, а також принципи фільтрування інформації, яка їм надавалась, потребують окремого дослідження.

Зрозуміло, що КДБ діяв з розрахунку не лише на радянського, а й на західного споживача. Використовувались при цьому ті самі засоби. Основним друкованим рупором виступала газета «Вісті з України» та iii англомовна версія. До прикладу, того ж 1984 р. було ініційовано публікацію в них 85 статей відповідної тематики". У 1985 р. у рамках вже згаданої операції «Відплата» КДБ двічі організовував видання і подальше розповсюдження в США англомовної книжки «Шоб ми не забули» («Lest We Forget»), автором якої був вказаний лідер радянофільської Ліги американських українців Майкл Ганусяк, паралельно в Канаді поширено подібне видання під назвою «Ми звинувачуємо» («We Accuse») Валентина Стрикула ${ }^{48}$. На основі

${ }^{44}$ ГДА СБУ, ф. 16, спр. 1108 , арк. 35.

${ }^{45}$ ГДА СБУ, ф. 16, спр. 1081, арк. 302.

${ }^{46}$ Ірина Закринична та ін. упор., Кінолітопис: анотований каталог кіножурналів, документальних фільмів і кіно- $i$ телесюжетів (1976-1985) (Київ: Центральний державний кінофотофоноархів ім. Г. Пшеничного, 2015), 593.

${ }^{47}$ ГДА СБУ, ф. 16, спр. 1108, арк. 36.

${ }^{48}$ ГДА СБУ, ф. 16, спр. 1109, арк. 123; ГДА СБУ, ф. 16, спр. 1110, арк. 169-170. 
підготовлених КДБ матеріалів у 1987 р. шотландська телекомпанія зняла документальну стрічку «Британія - притулок нацистів» («Britain: A Nazi Safehouse»), яку впродовж липня-серпня того ж року було продемонстровано у США, Канаді, Австралії та Ізраїлі. Одним із iї антигероїв виступив колишній поліцейський Зварич ${ }^{4}$.

До написання окремих текстів або виступів на радіо залучались власне колишні колаборанти, їхні родичі, жертви нацистського на-

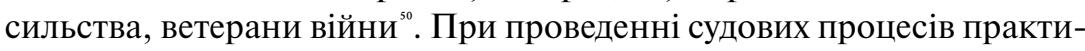
кувалось залучення так званих громадських обвинувачів, найчастіше з числа місцевих авторитетів. До прикладу, у випадку зі згаданими вище Дуфанцем, Бубелою і Рибачуком таким виступив Никифор Комісарик - колишній член КПЗУ, ветеран війни, учасник боротьби з українським націоналістичним рухом, персональний пенсіонер республіканського значення ${ }^{51}$. Деякі із заходів, що здійснювались КДБ, вимагали залучення ще більшого числа людей. Від їх імені організовувалось масове засилання листів до посольств західних держав з вимогою видати тих чи інших осіб. Лише в 1977 р. до посольства США в Москві було таким чином заслано 181 індивідуальний або колективний лист від імені понад 1500 осіб. Паралельно передбачалось проведення подібної кампанії, націленої на редакції американських єврейських газет та навіть президента США ${ }^{\text {s2 }}$. Для поширення інформації про конкретних осіб використовували також

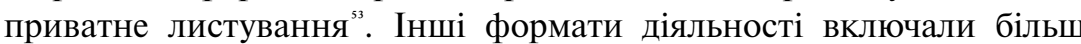
тісну комунікацію з аудиторією, як то у випадку виховних бесід, тематичних вечорів чи сходів, де під фото- та відеофіксацію присутні підписували колективні звернення до лідерів країн Заходу з вимогою припинити потурання колишнім колаборантам і видати їх до СРСР. Особлива програма подібних заходів була передбачена на 1986 р.,

${ }_{49}$ АУСБУВо0, ф. 5, спр. 23102, т. 3, арк. 202-203; ГДА СБУ, ф. 16, спр. 1117, арк. 23; гДА СБУ, ф. 16, спр. 1119, арк. 29.

50 Публікацію «покаяння» колишнього поліцейського з Рівненщини див.: Антон Петрук-Бушевський, «Завдяки соціалістичній гуманності», Вісті з України, № 16,1978 . Інший подібний приклад див.: Архів управління Служби безпеки України у Хмельницькій області (АУСБУХмО), ф. 6, спр. 404 (пакет «Текст виступу Олинця В.Д. від 05.09.1960 по Волинському радіо і газеті», без внутрішньої нумерації). У пресі, приміром, публікувалось і засудження Раїсою Ковальчук своїх братів Сергія та Миколи, теж колишніх поліцейських і громадян США: Раїса Ковальчук, «Не забудемо, не простимо", Миколи, теж колишніх поліцейс
Вісті з України, № 29, 1986.

${ }^{51}$ ГДА СБУ, ф. 5, спр. 67454, т. 33, арк. 60.

${ }^{52}$ ГДА СБУ, ф. 16, спр. 1061, арк. 124-125.

${ }_{53}$ Шищенко, «К вопросу о понятии и методах», 147-148. до 40-ї річниці Міжнародного воєнного трибуналу в Нюрнберзі ${ }^{54}$ До прикладу, 10 квітня 1986 р. на сході, що відбувся в будинку культури села Тур Ратнівського району на Волині мешканці цього та навколишніх населених пунктів вимагали у влади Великобританії видати колишнього поліцейського Зварича, який діяв тут під час нацистської окупації. Процес сходу був добре організований - виступали районний прокурор, православний священик, численні свідки. На даху будинку культури встановлено гучномовці. На фотографіях помітно, що деякі з присутніх тримали транспаранти 3 написами «Жителі с. Яревище вимагають видачі зрадника народу Кирила Зварича» та «Пам'ять не дає спокою». Під листом до британської прем'єрміністерки Маргарет Тетчер зібрано 2914 підписів. «І зараз, - йшлося у ньому, - зібравшись на сільський сход у зв'язку з 40-річчям Нюрнберзького процесу, ми звертаємось до Вас, пані прем'єр-міністр, 3 настійною просьбою не ігнорувати нашого голосу правди, почути крик зболених душ свідків злочинів вбивці К. Зварича і задовольнити нашу справедливу вимогу»". Серед іншого, на сході було продемонстровано згадану вище документальну стрічку «Без строку давності» ${ }^{56}$. Сам схід теж фільмувався і відповідні кадри були своєю чергою включені до стрічки «Іменем закону пам’яті» (режисер - той самий Татарець $)^{57}$. Вже в листопаді того ж року її демонстрували на міжнародній конференції «Уроки Нюрнберга» в Москві ${ }^{\text {s8 }}$

Так само й публічний судовий процес над групою колишніх поліцейських, про який йшлося на початку, був типовим прикладом того, як КДБ спільно з партійними структурами намагались інструменталізувати тему місцевої колаборації, тому не зайвим буде розглянути його детальніше. Слідство у справі Володимира та Арсентія Панасюків, Георгія та Івана Паламарчуків і Олексія Скибчика завершилось 28 квітня 1972 р. i, за погодження між УКДБ по Рівненській області та Рівненським обкомом КПУ, вже наступного місяця заплановано проведення процесу в селищі Рафалівка Володимирецького району - власне там, де діяли підсудні під час

${ }_{54}$ Детальніше див.: Віталій Нахманович, «Буковинський курінь і масові розстріли євреїв Києва 1941 р.», Український історичний журнал, № 3 (2007): 88.

${ }^{55}$ Володимир Канаш, «Переховування воєнного злочинця - теж злочин!», Вісті з України, № 17 , 1986; Шафета, «Відкритий лист».

${ }^{56}$ Шафета, «Відкритий лист».

${ }^{57}$ Центральний державний кінофотофоноархів України ім. Г. С. Пшеничного, спр. 10639.

${ }^{58}$ Євген Валевський, «Історія закликає до пильності: нотатки з міжнародної конференції «Уроки Нюрнберга»», Вісті з України, № 49, 1986. 
нацистської окупації. Проте провели його таки у Володимирці, при чому пізніше планованого спершу терміну, розтягнувши аж на 20 днів - з 6 по 26 червня 1972 р..$^{60}$ Очевидно, це було викликано потребою належної підготовки до майбутнього процесу. УКДБ по Рівненській області спеціально сформував оперативну групу, учасники якої були негласно присутніми на процесі. Серед завдань, що стояли перед ними, - фіксація реагування місцевого населення на процес; особлива увага зверталась на поведінку родичів підсудних, збір інформації щодо інших співробітників Рафалівської районної поліції, якими цікавився КДБ

Приміщення Володимирецького будинку культури, розраховане на 500 осіб, щодня було переповнене людьми. Особливо співробітники КДБ відзначали вагомий відсоток молоді серед присутніх. 28 червня 1972 р., у день оголошення вироку, люди заповнили не лише приміщення будинку культури, а й площу біля нього, тому для того, аби всі охочі могли почути вирок, було встановлено радіодинамік ${ }^{62}$.

3 огляду на те, що передбачалось охопити ще більшу аудиторію, багато уваги було приділено пропагандистському супроводу процесу, зокрема висвітленню його в пресі та по радіо, задля чого забезпечено присутність на ньому кореспондентів обласних газет «Червоний прапор» та «Зміна»". Тематичні акценти майбутніх публікацій були теж наперед визначені. 3 одного боку, це мало унеможливити шкідливу, з точки зору влади, інтерпретацію подій, тим більше, що під час процесу змушені були артикулюватись теми, витіснені 3 офіційного радянського канону про війну, як то Голокост чи український націоналістичний рух. 3 іншого боку, особлива увага зверталась на аспекти, що вважались особливо актуальними. До таких, приміром, відносилось зображення «сіоністів», під якими мали на увазі релігійних лідерів та співробітників внутрішньої адміністрації в Рафалівському гетто, не менші співучасники здійснення Голокосту, аніж нацисти і місцеві колаборанти. Така увага до цього питання була викликана як загалом антиізраїльським вектором у радянській політиці, такі внутрішніми проблемами, зокрема значним зростанням

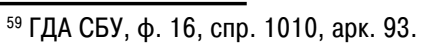

${ }^{60}$ ГДА СБУ, ф. 16, спр. 1011, арк. 48.

${ }^{61}$ ГДА СБУ, ф. 16, спр. 1011, арк. 48; ГДА СБУ, ф. 16, спр. 1012, арк. 117.

62 ГДА СБУ, ф. 16, спр. 1012, арк. 116.

${ }^{63}$ ГДА СБУ, ф. 16, спр. 1010, арк. 93; ГДА СБУ, ф. 16, спр. 1011, арк. 49, 77, 308-309.
3 початку 1970-х рр. чисельності репатріантів до Ізраїлю ${ }^{64}$ Приміром, в одному з документів КДБ вказувалось: «При цьому передбачено також на основі слідчих матеріалів на раніше засудженого до ВМП карателя, єврея Сигала-Сиголенка, продемонструвати блокування українських націоналістів і єврейських сіоністів у боротьбі з Радянською владою в роки Великої Вітчизняної війни і на сучасному етапі»" Хаїм Сигал - це львівський єврей, який в період нацистської окупації видавав себе за українця Кирила Сиголенка і служив у місцевих поліцейських структурах на Рівненщині, за що в березні 1952 р. був засуджений до розстрілу ${ }^{6}$. Хоча його особа була досить зручною для пропагандистського викривання «сіоністів», проте до подій у Рафалівці він не мав жодного відношення. Очевидно, саме з цих причин випадок Сигала-Сигаленка не фігурував у публікаціях за 1972 р., проте антисіоністська тематика активно використовувалась під час процесу у Володимирці. Як зазначалось в одному із партійних звітів про його перебіг, «на судовому процесі йшла мова і про тих, хто допомагав цим запроданцям-карателям, викривалась мерзенна роль верхівки гетто, єврейської поліції, рабинів, які сприяли катам творити криваві злочини»". Якщо звернутися до тексту «Бахова гора» Федрицького, то простежується, що автор дійсно приділив чимало уваги зображенню рабинів, співробітників юденрату та служби порядку Рафалівського гетто як «вірних помічників» у здійсненні нацистського антиєврейського насильства, хоча в слідчих матеріалах про їх роль майже не йшлося ${ }^{68}$.

Проте одна справа запланувати щось, а інша - реальна реакція аудиторії. Якою вона була? Підсумовуючи результати діяльності за 1972 р., голова КДБ УРСР Федорчук писав: «У Сімферополі, райцентрах Рівненської та Волинської областей проведено відкриті судові процеси, які широко висвітлювались по радіо і в пресі. Вони відіграли важливу роль у подальшому викритті антинародної сутності

64 У 1972 р. з СРСР до Ізраїлю репатріювалось близько 30 тис. осіб. Див.: Татьяна Носенко и Нина Семенченко, Напрасная вражда: очерки советско-израильских отношений 1948-1991 гг. (Москва: Институт востоковедения РАН, 2015), 89

${ }^{65}$ ГДА СБУ, ф. 16, спр. 1011, арк. 49.

${ }_{66}^{66}$ ГДА СБУ, ф. 5, спр. 67436, т. 1-4. Перший текст про випадок Сигала-Сиголенка опублікували у 1980-х рр. Теодор Гладков та Борис Стекляр, співробітники УКДБ по Рівненській області. Див. Теодор Гладков и Борис Стекляр, «Рассказы полковника Бонаря», в Чекисты рассказывают, сост Владимир Листов (Москва: Советская Россия, 1985), 6: 146-155.

${ }^{67}$ Склокіна, «Радянська політика пам'яті про колаборацію», 127.

${ }^{68}$ Федрицький, «Бахова гора», 85-86. 
українських і татарських націоналістів, їх кривавих злодіянь, тісного зв'язку з каральними органами фашистської Німеччини і сприяли відриву з-під впливу українських націоналістів і татарських автономістів політично незрілої частини громадян, які потрапили в оману» ${ }^{69}$. Звіт Рівненського обкому КПУ так само запевняв, що процес «відіграв важливу роль у викритті злодіянь фашизму, українського буржуазного націоналізму, релігійного сектантства та сіонізму, у вихованні населення області в дусі радянського патріотизму, соціалістичного інтернаціоналізму, непримиренності до будь-яких ворогів радянського народу» ${ }^{70}$.

Задля досягнення таких результатів співробітники КДБ повинні були непомітно коригувати хід процесу так, аби він не виходив за заплановані рамки. Основна небезпека була з боку родичів підсудних. Принаймні у кількох випадках вони намагались вплинути на свідків, але співробітники КДБ одразу нейтралізували такі спроби. Зокрема, з Рівного до Володимирця 6 червня 1972 р., у перший же день процесу, прибула Любов Журавльова, племінниця підсудного Георгія Паламарчука, зі своїм чоловіком. КДБ вже займався ними на етапі слідства, підозрюючи в намаганні вплинути на його перебіг. У Володимирці вони спробували встановити контакт з підсудними та потерпілими. Вже наступного дня КДБ організував ïx відклик на місця роботи, змусивши таким чином повернутись до Рівного". Дружина іншого підсудного, Івана Паламарчука, намагалась вплинути на двох свідків, аби ті відмовились від своїх попередніх зізнань. Цей факт був оголошений під час процесу ${ }^{\prime 2}$ Загалом змінив свої покази лише один зі свідків, Севастьян Скибчак, що КДБ пояснював результатом впливу на нього родичів підсудних ${ }^{73}$. Як і планувалось, у ході процесу співробітникам КДБ вдалося отримати інформацію про інших місцевих колаборантів ${ }^{74}$. Принаймні один із них, колишній поліцейський Яким Гузій, опинився на лаві підсудних під час публічного судового процесу, що відбувся в тому самому Володимирці в листопаді 1974 p. ${ }^{7 s}$

${ }^{69}$ ГДА СБУ, ф. 16, спр. 1020, арк. 11.

${ }^{70}$ Склокіна, «Радянська політика пам'яті про колаборацію», 127.

${ }^{71}$ ГДА СБУ, ф. 16, спр. 1011, арк. 78-79.

72 ГДА СБУ, ф. 16, спр. 1011, арк. 184.

${ }^{73}$ ГДА СБУ, ф. 16, спр. 1011, арк. 284.

${ }^{74}$ ГДА СБУ, Ф. 16, спр. 1011, арк. 78, 285.

${ }^{75}$ АУСБУРО, ф. 4, спр. 19099, т. 1-11.
Відносно процесу у Володимирці вдалося виявити ряд джерел, які дозволяють хоча б частково пролити світло на сприйняття подібних судових процесів місцевим населенням. Як вже згадувалось, співробітники оперативної групи УКДБ по Рівненській області негласно перебували на процесі, у тому числі для фіксації як реагування присутніх на ньому, так і характеру подальших обговорень, що відбувались, приміром, у трудових колективах. У більшості випадків занотовані ними у відповідних донесеннях оцінки були цілком позитивними. Будь-які намагання підсудних виправдати себе чи відмовитись від попередніх показів у залі зустрічали вигуками «гади», «мучителі», «вбивці» ${ }^{76}$ «Чому з ними вовтузяться? - викрикувала молодь. - Це зайва трата часу, їх всіх треба на одну мотузку»". Оголошення вироку супроводжувалось аплодисментами і вигуками «Мало гадам!» ${ }^{78}$. Навіть більше, вони вступали в суперечки з тими, хто дозволяв собі висловлюватись критично до того, що відбувалося. Коли один з присутніх, бухгалтер Павло Куц, під час перерви в засіданні заявив, мовляв, «дарма їх судять, вони нічого не робили, стріляли німці», то з ним почали сперечатись молоді люди, доводячи, що радянська влада ще занадто гуманно поводиться стосовно таких «паразитів». Після цієї суперечки Куц більше на процесі не з'являвся" ${ }^{\prime 9}$ Так само свідок Скибчик після зміни своїх показів був оточений обуреним натовпом: «...ти продажна шкура, мало тебе лупцювали в поліції, треба було тобі, негіднику, дати більше, щоб не хитрував. А ще називаєш себе комсомольцем» ${ }^{80}$

Зафіксовані співробітниками КДБ вислови часто зводились до вимог якнайжорстокішого покарання підсудних чи навіть нарікань на надмірний гуманізм з боку влади. Приміром, колгоспниця Малярчук говорила: «Таких паразитів треба катувати, як вони це робили» . Водій автобуса Калинка під час розмови зі співробітниками заявляв: «Якби мені сказали задавити їх автобусом, то рука в мене на кермі не здригнулась би». «Шкода бруднити машину об таку мерзоту, - заперечував йому один із колег. - Краще їх зав'язати в мішок і втопити 
в глухому болоті, куди й люди не ходять» ${ }^{82}$ Подібно висловлювався вчитель фізкультури Гаврилюк: «Я б на місці судді не виносив жодного вироку, а розпеченим залізом випік би їм на лобі «кат», «вражина» і пустив серед людей, аби кожен знав, хто живе серед них, і міг сказати йому, що ти, сволота, пив людську кров і тобі не місце серед них» ${ }^{83}$.

Особливо відслідковували в КДБреакціюна процесу Володимирці, передусім на його антисіоністську складову, серед етнічних євреїв. У спеціальному повідомленні від 11 серпня 1972 р. наводились висловлювання, зафіксовані в різних містах радянської України. Частина з них цілком збігались із інтерпретацією, що була запропонована у відповідних публікаціях. До прикладу, вчителька Есфір Кантаржі з Одеси висловлювалась так: «Яка ницість, яка підлість допомагати катам свого народу. Голда Меїр мало чим відрізняється від цих покидьків. Вона заманює євреїв до Ізраїлю, де вони приречені на важке життя» ${ }^{84}$. Поряд 3 цим прослідковувались і протилежні випадки, дехто навіть нарікав, що подібні публікації провокують антисемітські настрої в суспільстві, замовчують участь євреїв в антинацистському спротиві. Показовою є реакція інженера Семена Беренштейна з Києва: «Влада останнім часом все частіше намагається через пресу компрометувати сіоністів і тим самим відвести від себе удар світової громадської думки. Ці газети нехай вони самі й читають. Ми їх читати не будемо» ${ }^{85}$.

Іншим джерелом можуть слугувати індивідуальні та колективні листи, які надходили на адресу виїзної сесії Рівненського обласного суду під час процесу у Володимирці. Вони згадувались і навіть фрагментарно цитувались у донесеннях КДБ та «Баховій горі» Федрицького ${ }^{86}$. Однак, що важливо, збереглись і їхні повні оригінальні версії - сім листів, з яких чотири від трудових колективів і три від колишніх учасників радянського партизанського руху ${ }^{87}$. Це типові зразки комунікації з владою по-радянськи - своєрідні ритуальні послання, в яких важливішим був навіть не зміст, а мова, якою вони були написані. Тому листи були переповнені ідеологемами на кшталт «священної війни» або «українських буржуазних націоналістів».

\footnotetext{
${ }^{82}$ ГДА СБУ, ф. 16, спр. 1011, арк. 307-308.

${ }^{83}$ ГДА СБУ, ф. 16, спр. 1011, арк. 308.

${ }^{84}$ ГДА СБУ, Ф. 16, спр. 1013, арк. 255.

${ }^{85}$ ГДА СБУ, ф. 16, спр. 1013, арк. 257.

${ }^{86}$ ГДА СБУ, ф. 16, спр. 1011, арк. 185, 308, 329-331; Федрицький, «Бахова гора», 90-91.

${ }^{87}$ АУСБУРО, ф. 4, спр. 19090, т. 15, арк. 166 (пакет «Листи трудящих на адресу суду», без внутрішньої нумерації).
}

Підсудні називались «відщепенцями»- терміном особливо популярним у тодішньому радянському публічному дискурсі ${ }^{88}$. Цим насамперед чітко декларувалась соціальна дистанція між підсудними та правильними радянськими громадянами, як автори листів себе позиціонували, свого роду запевнення у власній лояльності. До прикладу, в листі колективу середньої школи села Полиці Володимирецького району писалось: «Нам невимовно шкода, що така людина як Паламарчук Іван носила звання вчителя, маючи в душі зовсім не те, чому вчила дітей»". Так само описувався травматичний досвід нацистської окупації в населених пунктах Володимирецького району, боротьба в лавах радянських партизан або РСЧА. Усі листи закінчувались однаковою вимогою - розстріляти підсудних. «Обсудивши на зборах злочинні дії зрадників народу, - читаємо в колективному листі колгоспників села Великі Цепевичі Володимирецького району, - ми просимо обласний суд застосувати до них найвищу міру покарання, щоб вони більше не ходили по нашій святій землі, не радувались нашим досягненням» ${ }^{90}$ Це власне була та реакція, яку влада, зокрема й КДБ, очікувала. Єдина несподіванка - у листах згадувались єврейські жертви, проте не було жодного слова про «сіоністів» і їхню роль у здійсненні нацистських злочинців, попри те, скільки уваги на цій темі акцентували організатори процесу.

Загалом, усе це засвідчує, що пересічні громадяни цілком визнавали легітимність дій радянської влади в напрямку переслідування колишніх колаборантів. При цьому до таких настроїв схилялись навіть ті, кого можна з упевненістю назвати антирадянськи налаштованими. До прикладу, львівська дисидентка Ірина Калинець, засуджена до 9 років ув’язнення, скаржилась у серпні 1972 р.: «Чи заслужила я такий термін? (Гітлерівському посіпаці у Володимирці Ровенської області дали тільки 10 р.)»".

Отже, у 1960-1980-х рр. КДБ ініціював проведення численних публічних судових процесів над місцевими колаборантами як частину ширшої кампанії з інструменталізації подій Другої світової війни, нацистської окупації та Голокосту. Активна участь КДБ у створенні та розповсюдженні пропагандистської продукції як для внутрішнього,

\footnotetext{
${ }^{88}$ Пётр Червинский, Язык советской действительности: семантика позитива в обозначении лиц (Тернополь: Крок, 2012), 310-311.

${ }^{89}$ АУСБУРО, ф. 4, спр. 19090, т. 15, арк. 166

${ }^{90}$ АУСБУРО, ф. 4, спр. 19090, т. 15, арк. 166

${ }_{91}$ Архів управління Служби безпеки України у Львівській області (АУСБУлО), ф. 6, спр. П-19483, т. 5, арк. 193.
} 
так і закордонного споживача $є$ безумовною. Майже завжди за цією діяльністю було намагання використати травматичну тему для вирішення актуальних політичних питань. Відкритим залишається запитання чи можна стверджувати, що активна залученість КДБ до описаних процесів означала і те, шо його співробітники таким чином поширювали своє корпоративне бачення проблеми місцевої колаборації, до прикладу, ототожнення колаборантів 3 «оунівцями» чи «сіоністами», навіть тоді, коли жодних підстав для цього не було. Ще однією проблемою, вартою стати темою окремого дослідження, $є$ простеження того, наскільки штампи, створені в межах радянського публічного дискурсу в 1960-1980-х рр., продовжили використовуватись і після розпаду СРСР. Одним з джерел для такого аналізу може стати кореспонденція, надіслана в 1990-х рр. на адресу Урядової комісії з вивчення діяльності ОУН-УПА. Це листи з усіх куточків України, індивідуальні та колективні, як «за», так і «проти». Автори лише невеликої частини з них були безпосередніми учасниками або свідками подій, отже, могли навести факти з власного досвіду. Більшість же листів надходила від органів місцевого самоврядування, трудових колективів, ветеранських організацій тощо. Вони були досить схожими на проаналізовану вище кореспонденцію, отриману в ході процесу у Володимирці в червні 1972 р., до прикладу, через використання подібних ідеологем на кшталт «українських буржуазних націоналістів». Часто в них прямо апелювали до радянських публікацій 1960-1980-х рр. чи результатів проведених тоді ж публічних судових процесів ${ }^{22}$ У деяких листах можна зустріти навіть знайомі імена місцевих колаборантів, популяризовані свого часу за участі КДБ, як-от неодноразово згадуваного нами Зварича".

\section{Andrii Usach \\ «DON'T LET THEM STEP ON OUR HOLY GROUND»: KGB UKRAINIAN SSR AND THE POLITICS OF MEMORY ON LOCAL COLLABORATION, 1960-1980's}

In 1960-1980s, the Soviet Ukraine adopted a practice of public court proceedings that became an essential part of the so-called «second wave» of ex-collaborators persecution in the Ukrainian SSR. Initiated by Com-

\footnotetext{
${ }_{92}$ Олександра Веселова упор., Національне примирення чи конфронтація? Збірник документів (Київ: Інститут історії України НАНУ, 1999), 110-111, 190, 298, 474.
}

${ }^{93}$ Веселова, упор. Національне примирення чи конфронтація?, 259. mittee for State Security (KGB), these proceedings represented an important part of a larger campaign on the instrumentalization of the events of World War II, Nazi occupation and the Holocaust. KGB's active involvement in the creation and distribution of propaganda products among both domestic and foreign consumers is indisputable. Usually this activity would touch on a sore point in order to solve relevant political issues.

A major external factor affecting the KGB's activity in those years was «the cold war», the aggravation of which began in early 1960s. In this regard, KGB Ukrainian SSR focused attention on the Ukrainian diaspora, as they saw a threat in the fact that the Western intelligence services were using it for anti-Soviet purposes, including private contacts with relatives living in Ukraine. That is why, since early 1960s, there was a trend to accumulate and disclose information about the members of diaspora communities, who cooperated with Nazi Germany during World War II. The main goal thereupon was to label all these communities as total collaborators and Western countries as those that deliberately provide them with a shelter.

An important role in contextulazing the KDB's activity in the stated period belongs to internal factors, particularly, to the struggle with national movements - Ukrainian, Crimean Tatar, Jewish, - dissident groups and religious denominations. It was even more important in terms of a simultaneous shaping of the «common Soviet identity» and a myth of the Great Patriotic War as a part and center of this identity.

This article explores the role KGB Ukrainian SSR played in instrumentalizing local collaboration in 1960-1980s. The author seeks to trace the way Ukrainian population responded to this activity in short- and long-term perspectives. The author leans on the archives of Security Service of Ukraine (SBU), which have recently become accessible.

Key words: Collaboration, KGB of the Ukrainian SSR, trials, instrumentalization, participation in the Holocaust.

\section{Bibliography}

Artizov, Andrej i dr., sost. Reabilitacija: kak jeto bylo. Dokumenty Prezidiuma CK KPSS i drugie materialy. Moskva: MFD, 2000.

Babii, Borys, i Hlib Chanhuli. «Suvori uroky istorii.» Visti z Ukrainy, № 6, 1987.

Bazhan, Oleh. «Reformuvannia orhaniv derzhbezpeky URSR u 1950 pershii polovyni 1960-kh rr.» V Radianski orhany derzhavnoi bezpeky v Ukraini (1918-1991 rr.): istoriia, struktura, funktsii, uporiadnyky Oleh Bazhan i Roman Podkur, 312-333. Kyiv: Instytut istorii Ukrainy NANU, 2013. 
Bazhenov, Nikolaj. «Nerushimost' principov Njurnberga i sotrudnichestvo gosudarstv $\mathrm{v}$ presledovanii nacistskih voennyh prestupnikov.» V Njurnbergskij process i sovremennost'. Moskva: Institut gosudarstva i prava Akademii nauk SSSR, 1986.

Chervinskij, Pjotr. Jazyk sovetskoj dejstvitel'nosti: semantika pozitiva v oboznachenii lic. Ternopol': Krok, 2012.

Exeler, Franziska. «The Ambivalent State: Determining Guilt in the Post-World War II Soviet Union.» Slavic Review 75, no. 3 (2016): 606-629.

Fedrytskyi, Oleksandr. «Bakhova hora.» V Zuby drakona. Publitsystychni narysy i pamflety, 78-91. Kyiv: Dnipro, 1988.

Gladkov, Teodor, i Boris Stekljar. «Rasskazy polkovnika Bonarja.» V Chekisty rasskazyvajut, sostavitel' Vladimir Listov, 6: 146-155. Moskva: Sovetskaja Rossija, 1985.

Jumashev, Mihail, A. Kaliteevskaja i R. Vladimircev, sost. Sbornik zakonov SSSR i ukazov Prezidiuma Verhovnogo Soveta SSSR: 1938-1975. Moskva: Izvestija Sovetov deputatov trudjashhihsja SSSR, 1975.

Kanash, Volodymyr. «Perekhovuvannia voiennoho zlochyntsia - tezh zlochyn!» Visti z Ukrainy, № 17, 1986.

«Karatel' izoblichen.» Informacionnyj bjulleten' KGB SSSR, № 4 (1990): 6 .

Kokurin, Aleksandr i Nikita Petrov, sost. Lubjanka: Organy VChK-OGPU-NKVD-MGB-MVD-KGB, 1917-1991: spravochnik. Moskva: MFD, 2003.

Koposov, Nikolaj. Pamjat'strogogo rezhima: istorija i politika v Rossii. Moskva: Novoe literaturnoe obozrenie, 2011.

Kovalchuk, Raisa. «Ne zabudemo, ne prostymo.» Visti z Ukrainy, № 29, 1986.

Lapinskij, N. i V. Shmyganovskij. «U poslednej cherty.» Izvestija, № 238, 1966.

Makarov, Aleksej, Nikolaj Kostenko i Gennadij Kuzovkin, sost. Vlast' i dissidenty: iz dokumentov KGB i CK KPSS. Moskva: Moskovskaja Hel'sinskaja Gruppa, 2006.

Nakhmanovych, Vitalii. «Bukovynskyi kurin i masovi rozstrily yevreiv Kyieva 1941 r.» Ukrainskyi istorychnyi zhurnal, № 3 (2007): 76-97.

Nosenko, Tat'jana, i Nina Semenchenko. Naprasnaja vrazhda: ocherki sovetsko-izrail'skih otnoshenij 1948-1991 gg. Moskva: Institut vostokovedenija RAN, 2015.

«Nota MID SSSR posol'stvu Velikobritanii v Moskve.» Izvestija, № 123, 1972.
Pastushenko, Tetiana. ««Pravosuddia» po-radiansky: kvalifikatsiia spivpratsi z natsystamy v SRSR, 1941-1956 rr.» Storinky voiennoi istorii Ukrainy 16 (2013): 125.

Penter, Tanja. «Local Collaborators on Trial: Soviet War Crimes Trials under Stalin (1943-1953).» Cahiers du Monde russe 49, no. 2-3 (2008): 341-364.

Petruk-Bushevskyi, Anton. «Zavdiaky sotsialistychnii humannosti.» Visti z Ukrainy, № 16, 1978.

Prusin, Alexander V. «The «Second Wave» of Soviet Justice: The 1960s War Crimes Trials.» In Rethinking Holocaust Justice: Essays across Disciplines, edited by Norman J.W. Goda, 129-157. New York: Berghahn Books, 2018.

Shafeta, Polikarp. «Vidkrytyi lyst premier-ministrovi Velykobrytanii Marharet Tetcher.» Visti z Ukrainy, № 38, 1986.

Shishhenko, Vladimir. «K voprosu o ponjatii i metodah razlozhenija jemigrantskih antisovetskih organizacij.» Trudy vysshej shkoly KGB SSSR43 (1988): 152.

Simkin, Lev. «Death Sentence Despite the Law: A Secret 1962 Crimesagainst-Humanity Trial in Kiev.» Holocaust and Genocide Studies 27, no. 2 (2013): 299-312.

Sklokina, Iryna. «Radianska polityka pamiati pro kolaboratsiiu periodu natsystskoi okupatsii yak instrument natsionalnoi polityky: rehionalnyi aspekt.» Natsionalna ta istorychna pamiat 5 (2012): 118-141.

Veselova, Oleksandra, upor. Natsionalne prymyrennia chy konfrontatsiia? Zbirnyk dokumentiv. Kyiv: Instytut istorii Ukrainy NANU, 1999.

Vronska, Tamara. «Femida voiennoi doby i tsyvilne naselennia.» Storinky voiennoi istorii Ukrainy 3 (1999): 100-119.

Weiner, Amir. Making Sense of War: The Second World War and the Fate of the Bolshevik Revolution. Princeton: Princeton University Press, 2001.

Zakrynychna, Iryna ta in., upor. Kinolitopys: anotovanyi kataloh kinozhurnaliv, dokumentalnykh filmiv i kino- i telesiuzhetiv (1976-1985). Kyiv: Tsentralnyi derzhavnyi kinofotofonoarkhiv im. H. Pshenychnoho, 2015.

\section{Archives}

Arkhiv upravlinnia Sluzhby bezpeky Ukrainy u Khmelnytskii oblasti (AUSBUKhmO). F. 6, spr. 404.

Arkhiv upravlinnia Sluzhby bezpeky Ukrainy u Lvivskii oblasti (AUSBULO). F. 6, spr. P-19483, t. 5. 
Arkhiv upravlinnia Sluzhby bezpeky Ukrainy u Rivnenskii oblasti (AUSBURO). F. 4, spr. 19090, t. 1-15; spr. 19099, t. 1-11.

Arkhiv upravlinnia Sluzhby bezpeky Ukrainy u Vinnytskii oblasti (AUSBUVO). F. 5, spr. 28506, t. 1-6.

Arkhiv upravlinnia Sluzhby bezpeky Ukrainy u Volynskii oblasti (AUSBUVoO). F. 5, spr. 23102, t. 1-3.

Arkhiv upravlinnia Sluzhby bezpeky Ukrainy u Zhytomyrskii oblasti (AUSBUZhO). F. 5, spr. 32437, t. 1-8.

Haluzevyi derzhavnyi arkhiv Sluzhby bezpeky Ukrainy (HDA SBU). F. 5, spr. 67436 , t. 1-4; spr. 67454 , t. 33; f. 16, spr. 110, 932, 1005, 1006 1010-1013, 1019, 1020, 1061, 1069, 1081, 1085, 1088, 1089, 1093, 1096, $1101,1104,1108-1110,1112-1114,1117,1119,1135,1137,1138$.

Tsentralnyi derzhavnyi kinofotofonoarkhiv Ukrainy im. H. S. Pshenychnoho, spr. 10639. 